\title{
It's all about the brand: place brand credibility, place attachment, and consumer loyalty
}

\author{
Bernd F. Reitsamer ${ }^{1}$ (1) - Alexandra Brunner-Sperdin ${ }^{2}$
}

Revised: 12 May 2020 / Accepted: 29 December 2020 / Published online: 30 January 2021

(c) The Author(s) 2021

\begin{abstract}
Despite the growing attention brand credibility attracts in recent marketing literature, little is known about the credibility of place brands and their relationship with consumers' loyalty. The present study builds on brand signalling and attachment theory to investigate whether credible place brands affect consumers' attachment formation, their subsequent word of mouth (WOM) and intention to return. Survey data from an Alpine winter sport destination reveal that place brand credibility is a key antecedent of consumers' attachment. Moreover, consistent with brand signalling theory, credible place brands exert a particularly strong direct effect on consumers' WOM. A positive effect on their intention to return, however, will result only if they feel attached with the place brand beforehand. Implications for marketing scholars and brand managers are offered.
\end{abstract}

Keywords Place branding $\cdot$ Brand credibility $\cdot$ Place attachment $\cdot$ Brand signalling $\cdot$ Consumer loyalty $\cdot$ WOM

\section{Introduction}

Clear, credible, and consistent brand signals help consumers to make inferences about a brand and its promise (Erdem and Swait 1998; Rao et al. 1999). Fulfilling a brands' promise is critical, as it impacts consumers' behaviour, which in turn influences overall firm performance, competitiveness, and profitability (Karanges et al. 2018; Henkel et al. 2007). Since it is difficult for consumers to evaluate the true quality of a brand, credible brand signals serve as vital means to reduce uncertainty about the quality of tangible and intangible brand attributes (Bettman and Park 1980).

Accompanied by increasing global competition, rising digitization aspects and international affairs that heighten uncertainty, the notion of brand credibility has become more important than ever, particularly in the field of place branding (Alexander et al. 2020; Zenker et al. 2017). This is not surprising, because an attractive place brand represents a destinations' major asset to overcome substitutability and

Bernd F. Reitsamer

bernd.reitsamer@uibk.ac.at

1 Department of Strategic Management, Marketing and Tourism, University of Innsbruck, Universitaetsstrasse 15, 6020 Innsbruck, Austria

2 University of Applied Sciences Kufstein, Andreas Hofer-Straße 7, 6330 Kufstein, Austria lacking differentiation (Pike 2005). Similarly, today's consumers are more flexible in their decision-making and favour place brands that keep their promises and provide unique, memorable travel experiences (e.g. Volgger and Pechlaner 2014). To compete successfully, brand managers thus need to understand what contributes to consumers' place attachment and how to gain their loyalty. But how does place brand credibility affect consumers' attachment and later behavioural outcomes?

Although brand credibility has received considerable attention in previous research in marketing (e.g. Erdem and Swait 1998), retailing (Guido et al. 2011), services management (Bougoure et al. 2016), consumer behaviour (Dholakia 1987), human-computer interaction (Shan 2016), and philosophy (Umeogu 2012), the credibility of place brands remains largely unexplored. Among the few contributions, Veasna et al. (2013) analysed the impact of destination source credibility on tourists' satisfaction at heritage sites. Relatedly, Zenker et al. (2017) examined the influence of place brand complexity on both residents' and tourists' behaviour. Yet it is striking that emotional, cognitive, and behavioural consequences of credible place brands received little attention in previous research. Particularly in the tourism industry, the primary field of application for place branding, consumers frantically look for brand experiences that convey credibility and trust. In the current research, we thus investigate the underlying mechanism of how informational cues (i.e. credible brand signals) 
influence consumers' place attachment and their subsequent response behaviour (Bianchi and Pike 2011). We assume that the perception of informational cues first involves a stimulus, followed by emotional and cognitive processing (i.e. attachment formation), and a favourable response towards the branding efforts of a place (Zeithaml 1988; Bolton and Drew 1991).

The present study makes three core contributions. First, in line with brand signalling theory (Erdem and Swait 1998), we postulate that the trustworthiness of information about a place exerts a persuasive effect on consumers' opinion (Bougoure et al. 2016). From this perspective, brand credibility can be achieved by acquiring informational cues from place brands. Consumers should thus only develop a favourable opinion towards a place when these cues are viewed as credible and reliable. Second, consistent with attachment theory (Mikulincer and Shaver 2007), we argue that place attachment represents an important emotional, cognitive, and functional mediating mechanism among informational cues (e.g. credible brand signals) and consumers' later responses. That is, when consumers perceive a place brands' marketing efforts to be trustworthy (Grisaffe and Nguyen 2011; Veloutsou and Moutinho 2009), the place brand becomes imbued with so much meaning that consumers use it to create a desired selfconcept and are likely to enter a relationship with the brand (Escalas 2004). Particularly when consumers have formed strong attachment with the place beforehand, place brand credibility should lead to increased behavioural outcomes. Third, we argue that consumers' sense of connectedness with a place can have a direct effect on their loyalty. Specifically, a high degree of place attachment should result in an increased desire to return to the setting and to spread positive word of mouth (WOM).

The purpose of this paper is to examine whether credible place brands facilitate brand-self connection and lead to a favourable approach behaviour. We first conceptualize the mechanism on how credible marketing efforts impact consumers' attachment formation and their loyalty by drawing on brand signalling (Erdem and Swait 1998), attachment theory (Mikulincer and Shaver 2007), and the self-expansion process (Aron et al. 2013). In a next step, consistent with our positivist perspective on brand signalling, we empirically test our research model using a survey-based approach (SEM) in an Alpine destination. The results provide novel insights for brand managers, showing how place attachment and consumer loyalty can be managed and improved by a deliberate placement of signals.

\section{Conceptual framework}

\section{Brand credibility}

Credibility can be defined as the degree to which an object is considered as a reliable and truthful source of information (Tirole 1988). The credibility of brands plays a significant role when consumer uncertainty arises due to imperfect and asymmetric information characterizing most product and service offerings (Erdem and Swait 2004; Erdem et al. 2006). In this context, brands can serve as credible signals to influence consumers' interpretations and actions through prior marketing communication strategies (Duncan and Moriarty 1998).

The concept of brand credibility is based on Hovland's et al. (1953) early work on the influence of source credibility on communication effectiveness. The authors conceptualize source credibility using a two-dimensional model composed of source expertise, the extent to which a communicator (i.e. a brand) is perceived as a valid source, and trustworthiness, the degree of confidence in the communicator's intent (Hovland et al. 1953). Branding research has further advanced this concept and identified three core dimensions determining the overall quality of brand signals (Erdem and Swait 1998; 2004): Brand signal clarity describes the receivers' perceptions of unambiguity within the information conveyed by the signaller (Nguyen 2009). Clear brand signals should be free from bias, facilitate timely understanding and reduce delays or potential misunderstandings. Brand signal credibility depicts whether the information sent out by the signaller is perceived as truthful and reliable by its receivers (i.e. consumers). Lastly, brand signal consistency refers both to the degree of convergence of exposure with the brand across all touchpoints and channels, but also to the extent to which the signal remains consistent over time (Erdem et al. 2006).

Prior research considered brand credibility as an antecedent or consequence in a series of consumer responses. In marketing and consumer behaviour, brand credibility was found to be an important predictor for purchase intentions (e.g. Tae et al. 2010) and attitudes towards the product, ad, or service provider (e.g. Lutz et al. 1983). Credible sources have been asserted greater attitude change power than sources having less of these dimensions, unless they are perceived as meaningful and trustworthy (Hovland and Weiss 1951; Johnson et al. 1968). Conversely, low levels or a complete lack of brand credibility were found to reduce consumers' quality perceptions and intentions to purchase, whereas strong and positive source credibility enhanced brand image and brand value, resulting in higher purchase intention (e.g. Goldsmith et al. 2000). 
More recently, brand credibility has been shown to predict brand preference and purchase intentions in the case of luxury restaurants (e.g. Jin et al. 2015) and to serve as a moderator among online brand experience and behavioural intentions in a destination context (e.g. Jiménez-Barreto et al. 2020).

\section{The credibility of place brands}

Place branding and the development of memorable destination brands have become key elements for destinations to compete in international terms (García et al. 2012; Zenker et al. 2017). Place branding (e.g. Kavaratzis and Hatch 2013) deals with the application of branding principles to places and their adjustment to the specific conditions of a setting. Place brands thereby not only identify and differentiate destinations from each other, they also convey a memorable experience uniquely associated with the setting and reinforce the collection of pleasurable memories (Tung and Ritchie 2011). Effective place branding thus reassures quality experiences and offers a fruitful means for brand managers to establish a unique selling proposition (Blain et al. 2005).

In the persuasion and decision-making process, the credibility of a place brand plays a key role as it reduces search costs for information (Erdem et al. 2006) and lowers perceived uncertainty (Erdem and Swait 2004). Brand managers, however, typically know more about their brand's offering than potential customers. In the light of this information asymmetry, it becomes difficult for consumers to evaluate the true quality of a brand. Credible brand signals (e.g. Spence 1974) thus serve as informational cues to enhance the believability of tangible and intangible brand attributes and help consumers in their decision-making. As signallers, destination management organizations hold privileged information about their brand and use a wide range of marketing mix elements and communication channels (e.g. written, personal, digital, non-verbal, or symbolic communication) to reduce consumers' uncertainty (Karanges et al. 2018). Since consumers typically lack complete information about the brand, they will carefully observe, interpret, and respond to brand signals depending on their own experience. The quality of the transmitted signals then depends on consumers' communication competence, access, familiarity, and flexibility (Sitkin 1992).

\section{Place brand credibility and place attachment}

For a place brand, it is crucial that its claims are truthful and believable to fully exploit its potential of lowering information-processing costs and perceived risk (Erdem and Swait 1998). When consumers trust a place brand and believe that it does not intend to break its promise, it is likely that a persuasive effect on their attachment follows (i.e. giving them a "sense of place"). Credible place brands can thus serve as vital means for self-expansion (Aron et al. 2013), as they positively influence the formation of place attachment.

The notion of brand attachment is rooted in psychology and was initially developed to understand infant's attachment to a primary caregiver (Bowlby 1969). Here, early meaningful relationships lead to the formation of experience-based internal working models of the self and others, which form the basis for perception, feeling, and behaviour in all later meaningful relationships (Bowlby 1969). Marketing literature adapted this concept and suggests that consumers can also develop attachment to market entities, including product brands (Schouten and McAlexander 1995), celebrities (Thomson 2006), or places (Williams and Stewart 1998). Park et al. (2010) thus define brand attachment as the strength of the bond that connects the consumer with the self, exemplified by rich and accessible cognitive representations that involve thoughts and feelings about the brand and the brand's relationship with the self. By categorizing the brand as part of the self, consumers then develop a sense of oneness with the brand and establish emotional and cognitive links that connect the brand with the self (Park et al. 2010).

Adapted to a destination context, attachment refers to a cognitive, emotional, and functional bond that consumers establish with a place (Halpenny 2006; Yuksel et al. 2010). Drawing on attachment theory (Mikulincer and Shaver 2007), consumers possess an intrinsic motivation for self-expansion, a desire to incorporate others (i.e. place brands) into their conception of the self (Aron et al. 2013). The greater the inclusion of the entity (i.e. the place brand) in the self-concept of the consumer, the stronger the bond becomes in consumers' minds (Park et al. 2010). Over time, this relationship between the self and the entity evolves, and so does one's attachment: consumers develop a feeling of "oneness" with the place and view its resources as their own (Aron et al. 1992). Importantly, attached consumers are not merely passive recipients of the place brand and its resources, they also invest social, financial, and time resources to maintain their relationship and their process of self-expansion (Park et al. 2010). Consequently, they engage in all kinds of behaviours to ensure a continuation of their brand relationship over time, particularly when their attachment is strong (e.g. Mikulincer 1998). Place brands with credible, clear, and consistent signals (Erdem and Swait 1998) should thus ease the process of self-expansion and foster the feeling of perceived oneness (Aron et al. 2013; Park et al. 2010). Consistent with prior studies from relationship marketing (e.g. Bolton et al. 2004; Morgan and Hunt 1994), positing that trustworthy brand signals positively influence brandself connection, we hypothesize: 
H1 Place brand credibility positively affects consumers' place attachment.

\section{Consumers' response behaviour}

Consumers tend to engage in all kinds of behaviours when attachment is strong (Mikulincer 1998). Likewise, attachment itself requires all kinds of behaviours to maintain the relationship across time (Park et al. 2010). Consistent with attachment theory (Mikulincer and Shaver 2007), positing that attachment manifests in rich cognitive representations which become reactivated at later stages and lead to behavioural outcomes (e.g. Sweeney and Swait 2008; Hosany et al. 2017), we argue that place attachment impacts consumers' loyalty, measured in terms of intention to return and WOM. Based on this rationale, the subsequent hypotheses are formulated:

H2 Place attachment positively impacts consumers' intention to return to a place.

H3 Place attachment positively impacts consumers' WOM activity.

The effect of place brand credibility on consumers' cognitive and behavioural responses constitutes a particularly important gap that has remained largely unaddressed so far. Even though previous studies showed that source credibility impacts purchase intention in the context of online brand advertisements (e.g. Visentin et al. 2019), price sensitivity (e.g. Erdem et al. 2002), and corporate brand equity (e.g. Hur et al. 2014), it remains largely unclear whether these findings also persist in the context of place brands. In other words, do credible place brands directly influence consumers' intention to return to a place and their engagement in positive WOM? More formally, we therefore hypothesize:
H4 Place brand credibility leads to increased intention to return among consumers.

H5 Place brand credibility leads to positive WOM among consumers.

Whereas previous research focused on either exploring the antecedents (e.g. Bougoure et al. 2016; Reitsamer et al. 2016) or consequences of place attachment in isolation (Prayag and Ryan 2011; Kyle et al. 2004), extant studies did not investigate the role of place attachment as mediator in greater depth (Hosany et al. 2017). This is surprising, because attachment per se represents an emotional, cognitive, and/or functional mediating mechanism among environmental inputs (e.g. a credible place brand) and consumers' later behavioural responses (Mikulincer and Shaver 2007). We thus assume that place brand credibility will lead to increased WOM activity and revisit intention (Thomson et al. 2005), particularly if consumers have formed a strong attachment with the destination beforehand. More formally:

H6a Place attachment mediates the path from place brand credibility to intention to return.

H6b Place attachment mediates the path from place brand credibility to WOM.

Figure 1 depicts the hypothesized relationships of our model.

\section{Method}

\section{Sample}

To test our hypothesized relationships, a self-administered field survey was conducted in the Alpine destination LechZürs during winter season 2016/17. Located in the Arlberg

Fig. 1 Research model

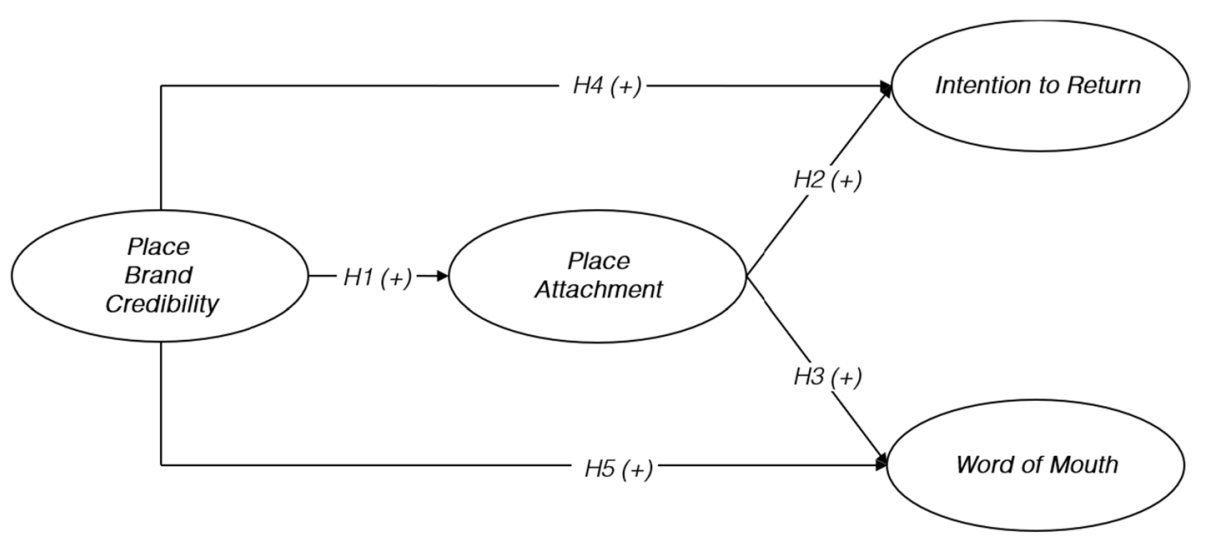

H6a, H6b: Mediating effects 
region in Austria, Lech-Zürs has grown to become one of the world's leading winter sport destinations with $305 \mathrm{~km}$ of adventurous slopes. The offered activities revolve around skiing, snowboarding, freeriding, cross-country skiing, tobogganing, and winter hiking. Besides its scenic and natural resources, the destination offers the world's highest density of gourmet dining restaurants, sport events such as 'The White Ring Speed Race', live music and après ski entertainment throughout the season and hosts business meetings on a regular basis, such as the 'Rotary Club winter meeting'. Data collection was administered by four scheduled interviewers and resulted in 302 returned questionnaires. The final, useable sample consists out of 243 questionnaires (41.6\% female, on average $41-50$ years old, $84 \%$ repeat time visitors; see Table 1). Only consumers' who had spent at least one full day in the destination were asked to participate in the study to ensure visitation of the place and its major spots.

\section{Measurement scales}

All study constructs were measured using reliable multiitem scales drawn from the literature. Place brand credibility $(\alpha=0.95)$ was operationalized with six statements from the brand credibility scale developed by Veasna et al. (2013) (e.g. "Information claims from $\mathrm{X}$ are believable"). For place attachment, eight items $(\alpha=0.94)$ from Prayag and Ryan (2011) were used (e.g. "I identify strongly with this destination"). Intention to return ( $\alpha=0.94)$ was operationalized by three statements suggested by Lam and Hsu (2006) (e.g. "The likelihood to visit X in the next 2 years is high"). Finally, we used three items from Zeithaml et al. (1996) to measure word of mouth $(\alpha=0.85)$ (e.g. "I would say positive things about this destination to other people"). All items were measured on a seven-point Likert-type scale anchored by " 1 -strongly disagree" to "7-strongly agree". All scales have been used in a destination context and performed well in terms of consistency, reliability, and validity in previous research (e.g. Jiménez-Barreto et al. 2020; Wang et al. 2020). Table 2 provides the full inventory of items used, their factor loadings and corresponding reliability.

\section{Results}

\section{Measurement model}

In a first step, internal consistency was assessed using EFA, item-to-total correlation, and Cronbach's alpha as firstgeneration criteria (e.g. Churchill 1979). Model parameters were further estimated with the help of confirmatory factor analysis (CFA). For an assessment of the psychometric properties of our scales, a four-factor measurement model was estimated using full information maximum likelihood
Table 1 Demographic profile of respondents

\begin{tabular}{|c|c|}
\hline Demographics & $N=243(\%)$ \\
\hline \multicolumn{2}{|l|}{ Gender } \\
\hline Male & 58.4 \\
\hline Female & 41.6 \\
\hline \multicolumn{2}{|l|}{ Age } \\
\hline Under 20 & 7.4 \\
\hline $21-30$ & 23.5 \\
\hline $31-40$ & 21.0 \\
\hline $41-50$ & 27.6 \\
\hline $51-60$ & 13.6 \\
\hline $61-70$ & 4.9 \\
\hline 71 or over & 2.1 \\
\hline \multicolumn{2}{|l|}{ Nationality } \\
\hline Austria & 21.5 \\
\hline Germany & 38.4 \\
\hline United Kingdom & 11.6 \\
\hline Netherlands & 5.8 \\
\hline Norway & 5.0 \\
\hline Ireland & 2.9 \\
\hline Sweden & 2.5 \\
\hline Switzerland & 2.5 \\
\hline France & 1.7 \\
\hline United States & 1.2 \\
\hline Other & 6.9 \\
\hline \multicolumn{2}{|c|}{ Net income (in EUR) } \\
\hline$<1000$ & 11.8 \\
\hline $1001-2000$ & 10.9 \\
\hline 2001-3000 & 12.7 \\
\hline $3001-4000$ & 17.3 \\
\hline $4001-5000$ & 10.0 \\
\hline$>5000$ & 37.3 \\
\hline \multicolumn{2}{|l|}{ Number of visits } \\
\hline First time & 16.0 \\
\hline Repeat time & 84.0 \\
\hline \multicolumn{2}{|l|}{ Type of sport } \\
\hline Alpine skiing & 83.1 \\
\hline Snowboarding & 11.1 \\
\hline Other & 5.8 \\
\hline \multicolumn{2}{|l|}{ Personal skill level } \\
\hline Beginner & 5.8 \\
\hline Advanced & 49.4 \\
\hline Professional & 36.6 \\
\hline Racer & 7.0 \\
\hline None & 1.2 \\
\hline
\end{tabular}

estimation in Mplus 7.0 (Muthén and Muthén 1998-2012). Four cases were eliminated before model estimation due to missing values. Because there is no single conclusive test of significance of the model fit (Hu and Bentler 1999), we evaluated overall model fit based on a combination of 
Table 2 Measurement model

\begin{tabular}{|c|c|c|c|c|c|}
\hline Constructs & Items & CFA & $\mathrm{CR}$ & AVE & $\alpha$ \\
\hline \multirow[t]{6}{*}{ Place brand credibility (PBC) } & $\mathrm{PBC} 1$ & 0.81 & \multirow[t]{6}{*}{0.95} & \multirow[t]{6}{*}{0.74} & \multirow[t]{6}{*}{0.95} \\
\hline & $\mathrm{PBC} 2$ & 0.86 & & & \\
\hline & PBC3 & 0.82 & & & \\
\hline & PBC4 & 0.85 & & & \\
\hline & PBC5 & 0.90 & & & \\
\hline & PBC6 & 0.92 & & & \\
\hline \multirow[t]{8}{*}{ Place attachment (ATT) } & ATT1 & 0.79 & \multirow[t]{8}{*}{0.95} & \multirow[t]{8}{*}{0.69} & \multirow[t]{8}{*}{0.94} \\
\hline & ATT2 & 0.89 & & & \\
\hline & ATT3 & 0.76 & & & \\
\hline & ATT4 & 0.79 & & & \\
\hline & ATT5 & 0.89 & & & \\
\hline & ATT6 & 0.85 & & & \\
\hline & ATT7 & 0.84 & & & \\
\hline & ATT8 & 0.81 & & & \\
\hline \multirow[t]{3}{*}{ Intention to return (IR) } & IR1 & 0.86 & \multirow[t]{3}{*}{0.94} & \multirow[t]{3}{*}{0.83} & \multirow[t]{3}{*}{0.94} \\
\hline & IR2 & 0.94 & & & \\
\hline & IR3 & 0.94 & & & \\
\hline \multirow[t]{3}{*}{ Word of mouth (WOM) } & WOM1 & 0.81 & \multirow[t]{3}{*}{0.86} & \multirow[t]{3}{*}{0.68} & \multirow[t]{3}{*}{0.85} \\
\hline & WOM2 & 0.79 & & & \\
\hline & WOM3 & 0.70 & & & \\
\hline Global fit & \multicolumn{5}{|c|}{$\begin{array}{l}\chi^{2}=338.832(d f=164) \\
\text { RMSEA }=0.067, \text { SRMR }=0.047, \\
\text { CFI }=0.95, \text { TLI }=0.94\end{array}$} \\
\hline
\end{tabular}

non-inferential fit indices. As the chi-square statistic is sensitive to sample size and is not relied solely as a basis for model fit assessment, we used CFI, TLI, SRMR, and RMSEA for evaluating the fit of our measurement and structural models (Kline 2015; Hair et al. 2014). The measurement model thus showed an acceptable fit $\left(\chi^{2}=338.83, d f=164\right.$, CFI $=0.95$, $\mathrm{TLI}=0.94, \mathrm{RMSEA}=0.067, \mathrm{SRMR}=0.047)$. All composite reliability estimates exceeded 0.86 , indicating internal consistency for our latent variables (Bagozzi and Yi 1988). Convergent validity was established since factor loadings of all constructs exceeded 0.50 and were significant $(t>1.96$, $p<0.05$ ) (Anderson and Gerbing 1988). Results also suggest strong discriminant validity, as the intercorrelations between pairs of constructs in Table 3 were less than the square root of the average variance extracted (AVE) estimates of the two constructs (Fornell and Larcker 1981; Hair et al. 2014).

Since we used a self-administered survey design, it is important to rule out common-method variance (CMV) as a source of bias in our results (Podsakoff et al. 2012). To control for CMV, procedural and statistical (ex-ante) approaches were used. Among procedural remedies, we inspected all scales to reduce ambiguity, separated the measurement of predictor and outcome variables in our questionnaire and ensured anonymity and privacy to our respondents (Malhotra et al. 2006). In a second step, we controlled for statistical remedies by introducing a common latent factor (CLF) to capture the common variance among all observed variables in our model. Following the approach suggested by Homburg et al. (2010), we compared an unconstrained CLFmodel with a fully zero-constrained CLF-model. The results demonstrate that the chi-square difference between both models is insignificant $\left(\chi^{2}=353.36, d f=149\right.$ vs. $\chi^{2}=373.78$, $d f=168 ; p>0.05)$, thus confirming that common-method variance is not a major concern in our study.

\section{Structural model and hypothesis testing}

Hypotheses were tested using structural equation modelling (Mplus 7.0) and a bootstrapping mediation analysis. The structural model revealed an acceptable fit by exceeding the cut-off criteria suggested by $\mathrm{Hu}$ and Bentler (1999) $\left(\chi^{2}=338.83, d f=164, \mathrm{CFI}=0.94, \mathrm{TLI}=0.93\right.$, RMSEA $=0.067, \mathrm{SRMR}=0.047$ ). The results confirm that brand signalling theory represents a valid and useful framework for research on place brand credibility (Table 4), as indicated by the significant, positive impact of destination brand credibility on place attachment $(\beta=0.676, p<0.001$; full support for H1). Subsequently, place attachment was found to exert a highly significant direct effect on consumers' intention to return $(\beta=0.489, p<0.001)$ and WOM $(\beta=0.399, p<0.05)$, thus supporting $\mathrm{H} 2$ and $\mathrm{H} 3$.
Table 3 Construct properties and shared correlations

\begin{tabular}{lcccccccc}
\hline Constructs & $M$ & SD & $\mathrm{CR}^{\mathrm{a}}$ & $\begin{array}{l}\text { Cronbach's } \\
\text { alpha }\end{array}$ & 1 & 2 & 3 & 4 \\
\hline 1. Place brand credibility & 5.90 & 1.09 & 0.95 & 0.95 & $0.74^{\mathrm{b}}$ & & & \\
2. Place attachment & 5.02 & 1.82 & 0.95 & 0.94 & $0.46^{\mathrm{c}}$ & $\mathbf{0 . 6 9}$ & & \\
3. Intention to return & 6.14 & 1.35 & 0.94 & 0.94 & 0.24 & 0.36 & $\mathbf{0 . 8 3}$ & \\
4. Word of mouth & 6.20 & 1.10 & 0.86 & 0.85 & 0.62 & 0.56 & 0.63 & $\mathbf{0 . 6 9}$ \\
\hline
\end{tabular}

Bold values refer to average variance extracted (AVE)

${ }^{\mathrm{a}}$ Construct reliability

${ }^{\mathrm{b}}$ Average variance extracted

${ }^{\mathrm{c}}$ Inter-construct squared correlations 
Table 4 Standardized estimates of direct and indirect paths

\begin{tabular}{llllrl}
\hline & Relationship & Estimate & Std. error & $t$ value & Supported \\
\hline Hypothesis & & & & & \\
H1 & PBC $\rightarrow$ ATT & $0.676^{* * *}$ & 0.041 & 16.593 & Yes \\
H2 & ATT $\rightarrow$ IR & $0.489 * * *$ & 0.088 & 5.545 & Yes \\
H3 & ATT $\rightarrow$ WOM & $0.399 * *$ & 0.078 & 5.142 & Yes \\
H4 & PBC $\rightarrow$ IR & 0.162 & 0.092 & 1.761 & No \\
H5 & PBC $\rightarrow$ WOM & $0.519 * * *$ & 0.077 & 6.752 & Yes \\
Bootstrap model & & & & \\
H6a & PBC $\rightarrow$ ATT $\rightarrow$ IR & $0.330^{* * *}$ & 0.068 & 4.870 & Yes \\
H6b & $\mathrm{PBC} \rightarrow$ ATT $\rightarrow$ WOM & $0.269 * * *$ & 0.057 & 4.759 & Yes \\
\hline
\end{tabular}

$P B C$ place brand credibility, ATT place attachment, IR intention to return, WOM word of mouth $* * * p \geq 0.001 ; * * p \geq 0.05$ and significant level at $t$ value $>1.96$
A bootstrap estimation with 1000 resamples in Mplus $7.0\left(\chi^{2}=437.61, d f=164, \mathrm{CFI}=0.94, \mathrm{TLI}=0.93\right.$, RMSEA $=0.084$, SRMR $=0.047$ ) further demonstrates that place attachment mediates the effect of place brand credibility on consumers' WOM activity $(\beta=0.269, p<0.001$; support for H6b). The direct effect, however, turned out to be much stronger ( $\beta=0.519, p<0.001$; support for H5), suggesting complimentary mediation (Zhao et al. 2010). Given that brand signals are credible and trustful, consumers will directly spread positive WOM, with attachment not necessarily relevant to cause WOM activity. Lastly, comparing the non-significant direct effect of place brand credibility on intention to return $(\beta=0.162, p>0.05$; rejection of $\mathrm{H} 4)$ with the highly significant mediation effect via place attachment $(\beta=0.330, p<0.001$; support for H6a), an indirectonly mediation of place attachment results. In other words, only if consumers' feel attached with the place brand, they will remain loyal and return to the destination. Comparing the magnitude and size of the obtained effects, consumers' intention to spread positive WOM reveals to be much more sensitive to credible signals and strong attachment than intention to return. This becomes evident when juxtaposing the size of the direct effects that place brand credibility exerts on WOM $(\beta=0.519, p<0.001)$ and intention to return $(\beta=0.162, p>0.05)$, but particularly when inspecting their total effects $(\beta=0.789, p<0.001$ vs. $\beta=0.493, p<0.001)$. Table 4 summarizes the obtained findings.

\section{Alternative models}

In addition to the integrative model illustrated in Fig. 1, we tested for alternative, theoretically plausible models (e.g. Hennig-Thurau et al. 2002). Given that our current model argues for complimentary mediation of place attachment, we decided to choose a model without direct effects of our antecedent variable (place brand credibility) on our central dependent variables WOM and intention to return (Model 1) as conceptual alternative. In addition, we inspected a model where the roles of our antecedent place brand credibility and our mediator (place attachment) are reversed (Model 2). Moreover, to control for the frequency of previous visitation, we added first versus repeat time visitation as covariate to our integrative model (Model 4).

We tested the aforementioned models using ML-SEM with Mplus 7.0. Comparisons based on non-inferential fit indices and probabilistic model selection criteria (AIC, BIC, and Log-Likelihood) confirm that the hypothesized model (Model 3) including direct effects of place brand credibility on our dependent variables is superior to all alternative models (see Table 5). Swapping place brand credibility with place attachment, by contrast, did not result in better model fit (Model 2), which confirms our theoretical arguments provided earlier. Model 4 shows slightly better (i.e. lower) alternative model fit criteria without changing the significance of the hypothesized relationships from Model 3. Given the lower non-inferential fit indices and the comparably high proportion of repeat time visitors (i.e. 84.0\%), which represents a limitation in our sample, Model 3 is considered as superior.

\section{Discussion}

Credible place brands are a key antecedent of consumers' attachment formation and their response behaviour. Confronted with an array of destination choices $(\mathrm{Qu}$ et al. 2011), memorable place brands that are clear, precise, and truthful in their information claims help consumers in making judgments, forming bonds, and developing loyalty towards a place. While place attachment directly affects consumers' loyalty in terms of WOM, it is an even more powerful mediating factor for their intention to return. Particularly if consumers' feel attached to a place, credible brand attributes will cause them to come back. By contrast, if they do not obtain a feeling of perceived oneness with the place during their stay, also the most credible and 
Table 5 Alternative models

\begin{tabular}{llllllllll}
\hline & $\chi^{2}$ & $d f$ & CFI & TLI & RMSEA & SRMR & AIC & BIC & LL \\
\hline Baseline model & 488.127 & 182 & 0.903 & 0.899 & 0.084 & 0.122 & $12,575.121$ & $12,741.121$ & -6239.560 \\
Model 1 & 387.555 & 166 & 0.930 & 0.920 & 0.075 & 0.072 & $12,478.774$ & $12,701.268$ & -6175.387 \\
Model 2 & 372.969 & 166 & 0.934 & 0.925 & 0.072 & 0.085 & $12,461.080$ & $12,683.574$ & -6166.540 \\
Model 3 & $\mathbf{3 3 8 . 8 3 2}$ & $\mathbf{1 6 4}$ & $\mathbf{0 . 9 4 5}$ & $\mathbf{0 . 9 3 6}$ & $\mathbf{0 . 0 6 7}$ & $\mathbf{0 . 0 4 7}$ & $\mathbf{1 2 , 4 2 0 . 6 8 1}$ & $\mathbf{1 2 , 6 5 0 . 1 2 7}$ & $-\mathbf{6 1 4 4 . 3 4 0}$ \\
Model 4 & 371.209 & 184 & 0.935 & 0.926 & 0.066 & 0.075 & $12,217.277$ & $12,451.362$ & -6040.639 \\
\hline
\end{tabular}

Bold values highlight the superior model

CFI Comparative Fit Index, TLI Tucker-Lewis Index, RMSEA Root Mean Square Error of Approximation, $S R M R$ Standardized Root Mean Square Residual, AIC Akaike Information Criterion, BIC Bayesian Information Criterion, $L L$ Log-Likelihood

Baseline model: PBC - ATT - IR/WOM (fixed)

Model 1: PBC-ATT - IR/WOM

Model 2: ATT-PBC-IR/WOM

Model 3: PBC - ATT - IR/WOM (with direct effects of PBC on IR/WOM)

Model 4: PBC - ATT - IR/WOM (with direct effects of PBC on IR/WOM; Covariate: F/R)

trustful communication or branding campaigns will not make them visit the place again. For influencing consumers' WOM activity, however, a different rationale emerges. Even though attachment shows a significant mediation effect between brand credibility and WOM, the direct effect reveals to be much stronger. This circumstance further underlines the predictive power of credible brands (Erdem et al. 2002), as they have the potential to directly affect consumers' WOM behaviour, with place attachment not necessarily being given.

Importantly, place brand credibility should be considered as antecedent to attachment formation in managerial decision-making, as our hypothesized model performed superior to alternative models inspecting its role as a mediating variable. Managers should thus focus on credible signalling in the first place, as this will positively affect consumers' attachment. Particularly when consumers are uncertain in their decision-making, informational cues can signal quality, such as, for example, consistency in product quality over time, charging price levels that fit the destination and its offerings or providing warranties such as free cancellation policies. Although the success of such marketing efforts will depend on market characteristics, consumer and competitive behaviour, it is important for managers to show long-term commitment to their signalling approach and assure consumers that their brand promises are kept (Erdem and Swait 1998). In other words, destination managers should invest steadily in credible marketing communication, as it constitutes a fundamental antecedent when building attachment with consumers. Managers could, for instance, launch (digital) communication campaigns to reinforce their brand's ability to reduce risk, generate group identification and reinforce its trustworthiness (e.g. by means of storytelling, innovative VR content, or well-known testimonials). Similarly, brand extensions in the sense of linkages among smaller destinations (such as strategic mergers or seasonal cooperation among destinations) could serve as categories where risk or collective identity matter.

\section{Limitations and future research directions}

Among limitations, it needs to be acknowledged that our study tested the notion of place brand credibility in a communitytype destination for the first time. Although our assumptions are strongly rooted in theory (i.e. brand signalling, attachment theory, self-expansion process) and our research model shows low complexity and a modest number of parameters, alternative modelling techniques (e.g. a variance-based approach such as PLS-SEM) or alternative measurement approaches for place attachment (e.g. focusing on its functional or emotional facets) might lead to different results. Results from different destination types (e.g. corporate destinations) or other cultural areas might furthermore vary considerably from our findings. Further research could provide deeper insights through testing and replicating our model in different settings. Particularly the scales for place brand credibility and place attachment could greatly benefit from further replication and a deeper exploration of alternative emotional and cognitive processing routes. Second, as the study only considers consumers' perceptions and their attachment at a certain point during their stay, future studies could analyse how place attachment and consumers' responses develop over time (e.g. Mittal et al. 1999). Longitudinal designs have previously been used to study variations in emotional responses over the context of a vacation (Nawijn et al. 2012), a similar approach could thus make sense for place attachment, particularly throughout later post-consumption stages. Third, future research should take sample-specific characteristics into account, as our study was made up of a sportive, international sample with a comparatively high net 
income $(65.6 \%>3000 \mathrm{EUR} / \mathrm{month})$ and a rather high degree of repeat time visitors (84\%). It would be interesting to study different consumer segments (e.g. first timers, purely recreational holidaymakers) or other forms of tourism and leisure (e.g. rural tourism, adventure tourism). Finally, this study pursued a consumer-centric view on place brand credibility in the tourism industry. Since tourists view place brands differently, develop attachment under varying circumstances and for different purposes than other stakeholder groups, it is of great importance to expand the scope of application towards residents, local entrepreneurs, or public policymakers in the future.

\section{Appendix}

Measurement of the study constructs

\begin{tabular}{|c|c|c|}
\hline Constructs & Mean & Std. deviation \\
\hline \multicolumn{3}{|l|}{ Place brand credibility $(\alpha=0.95)$} \\
\hline Information claims from $\mathrm{X}$ are believable & 5.80 & 1.07 \\
\hline $\begin{array}{l}\text { Over time, my experiences with } \mathrm{X} \text { led me } \\
\text { to expect it to keep its promises }\end{array}$ & 5.86 & 1.04 \\
\hline $\mathrm{X}$ is committed to delivering on its claims & 5.91 & 1.09 \\
\hline $\mathrm{X}$ has a name you can trust & 5.84 & 1.22 \\
\hline $\mathrm{X}$ has the ability to deliver what it promises & 6.02 & 1.05 \\
\hline $\mathrm{X}$ delivers what it promises & 5.96 & 1.06 \\
\hline \multicolumn{3}{|l|}{ Place attachment $(\alpha=0.94)$} \\
\hline $\begin{array}{l}\mathrm{X} \text { is the best place for what I like to do on } \\
\text { holidays }\end{array}$ & 5.42 & 1.60 \\
\hline $\begin{array}{l}\text { I am very attached to this holiday destina- } \\
\text { tion }\end{array}$ & 5.37 & 1.69 \\
\hline Holidaying in $\mathrm{X}$ means a lot to me & 5.59 & 1.50 \\
\hline $\begin{array}{l}\text { No other place can provide the same holi- } \\
\text { day experience as } \mathrm{X}\end{array}$ & 4.38 & 2.01 \\
\hline I identify strongly with this destination & 4.78 & 2.03 \\
\hline $\mathrm{X}$ is a very special destination to me & 5.14 & 1.81 \\
\hline $\begin{array}{l}\text { Holidaying here is more important to me } \\
\text { than holidaying in other places }\end{array}$ & 4.74 & 1.89 \\
\hline $\begin{array}{l}\text { I would not substitute any other destination } \\
\text { for the types of things that I did during } \\
\text { my holidays in X }\end{array}$ & 4.71 & 2.01 \\
\hline \multicolumn{3}{|l|}{ Intention to return $(\alpha=0.94)$} \\
\hline $\begin{array}{l}\text { The likelihood to visit } \mathrm{X} \text { in the next } 2 \text { years } \\
\text { is high }\end{array}$ & 6.15 & 1.33 \\
\hline I intend to visit $X$ in the next 2 years & 6.10 & 1.38 \\
\hline $\begin{array}{l}\text { I want to visit } X \text { again within the next } \\
2 \text { years }\end{array}$ & 6.16 & 1.35 \\
\hline \multicolumn{3}{|l|}{ Word of mouth $(\alpha=0.85)$} \\
\hline $\begin{array}{l}\text { I would say positive things about this desti- } \\
\text { nation to other people }\end{array}$ & 6.30 & 0.94 \\
\hline $\begin{array}{l}\text { I would recommend } \mathrm{X} \text { to someone who } \\
\text { seeks my advice }\end{array}$ & 6.33 & 1.09 \\
\hline
\end{tabular}

\begin{tabular}{lll}
\hline Constructs & Mean & Std. deviation \\
\hline $\begin{array}{c}\text { I would encourage my friends and relatives } \\
\text { to visit this destination }\end{array}$ & 5.98 & 1.26 \\
\hline
\end{tabular}

All variables were measured on a seven-point rating scale $(1=$ strongly disagree, $7=$ strongly agree $)$

Funding Open Access funding provided by University of Innsbruck and Medical University of Innsbruck.

\section{Compliance with ethical standards}

Conflict of interest On behalf of all authors, the corresponding author states that there is no conflict of interest.

Open Access This article is licensed under a Creative Commons Attribution 4.0 International License, which permits use, sharing, adaptation, distribution and reproduction in any medium or format, as long as you give appropriate credit to the original author(s) and the source, provide a link to the Creative Commons licence, and indicate if changes were made. The images or other third party material in this article are included in the article's Creative Commons licence, unless indicated otherwise in a credit line to the material. If material is not included in the article's Creative Commons licence and your intended use is not permitted by statutory regulation or exceeds the permitted use, you will need to obtain permission directly from the copyright holder. To view a copy of this licence, visit http://creativecommons.org/licenses/by/4.0/.

\section{References}

Alexander, A., C. Teller, and S. Wood. 2020. Augmenting the urban place brand-On the relationship between markets and town and city centres. Journal of Business Research 116: 642-654.

Anderson, J.C.J., and D.D.W. Gerbing. 1988. Structural equation modeling in practice: A review and recommended two-step approach. Psychological Bulletin 103 (3): 411-423.

Aron, A., E.N. Aron, and D. Smollan. 1992. Inclusion of other in the self scale and the structure of interpersonal closeness. Journal of Personality and Social Psychology 63: 596-612.

Aron, A., G. Lewandowski, D. Mashek, and E.N. Aron. 2013. The selfexpansion model of motivation and cognition in close relationships. In Oxford handbook of close relationships, ed. J.A. Simpson and L. Campbell, 90-115. New York: Oxford.

Bagozzi, R.P., and Y. Yi. 1988. On the evaluation of structural equation models. Journal of the Academy of Marketing Science 16 (1): 74-94.

Bettman, J.R., and C.W. Park. 1980. Effects of prior knowledge and experience and phase of the choice process on consumer decision processes: A protocol analysis. Journal of Consumer Research 7: $234-248$.

Bianchi, C., and S. Pike. 2011. Antecedents of destination brand loyalty for a long-haul market: Australia's destination loyalty among Chilean travelers. Journal of Travel \& Tourism Marketing 28 (7): 736-750.

Blain, C., S. Levy, and B. Ritchie. 2005. Destination branding: Insights and practices from destination management organizations. Journal of Travel Research 43 (4): 328-338. 
Bolton, R.N., and J.H. Drew. 1991. A longitudinal analysis of the impact of service changes on customer attitudes. Journal of Marketing 55 (1): 1-10.

Bolton, R., K. Lemon, and P. Verhoef. 2004. The theoretical underpinnings of customer asset management: A framework and propositions for future research. Journal of the Academy of Marketing Science 32: 271-292.

Bougoure, U.S., R. Russell-Bennett, S. Fazal-E-Hasan, and G. Mortimer. 2016. The impact of service failure on brand credibility. Journal of Retailing and Consumer Services 31: 62-71.

Bowlby, J. 1969. Attachment. New York: Basic Books.

Churchill, G.A. 1979. A paradigm for developing better measures of marketing construct. Journal of Marketing Research 16 (February): 64-73.

Dholakia, R.R. 1987. Source credibility effects: A test of behavioral persistence. Advances in Consumer Research 14: 426-430.

Duncan, T., and S.E. Moriarty. 1998. A communication-based marketing model for managing relationships. Journal of Marketing 62 (2): 1-13.

Erdem, T., and J. Swait. 1998. Brand equity as a signaling phenomenon. Journal of Consumer Psychology 7 (2): 131-157.

Erdem, T., and J. Swait. 2004. Brand credibility and its role in brand choice and consideration. Journal of Consumer Research 31 (1): 191-199.

Erdem, T., J. Swait, and J. Louviere. 2002. The impact of brand credibility on consumer price sensitivity. International Journal of Research in Marketing 19 (1): 1-19.

Erdem, T., J. Swait, and A. Valenzuela. 2006. Brands as signals: A cross-country validation study. Journal of Marketing 70 (1): 34-49.

Escalas, J.E. 2004. Narrative processing: Building consumer connections to brands. Journal of Consumer Psychology 14 (1-2): 168-180.

Fornell, C., and D. Larcker. 1981. Evaluating structural equation models with unobservable variables and measurement error. Journal of Marketing Research 18 (3): 39-50.

García, J.A., M. Gómez, and A. Molina. 2012. A destination-branding model: An empirical analysis based on stakeholders. Tourism Management 33 (3): 646-661.

Goldsmith, R., B. Lafferty, and S. Newell. 2000. The influence of corporate credibility on consumer attitudes and purchase intent. Corporate Reputation Review 3: 304-318.

Grisaffe, D.B., and H.P. Nguyen. 2011. Antecedents of emotional attachment to brands. Journal of Business Research 64 (10): 1052-1059.

Guido, G., G. Pino, and D. Frangipane. 2011. The role of credibility and perceived image of supermarket stores as valuable providers of over-the-counter drugs. Journal of Marketing Management 27 (3-4): 207-224.

Hair, J.F.J., W.C. Black, B.J. Babin, and R.E. Anderson. 2014. Multivariate data analysis. Upper Saddle River, NJ: Pearson Education.

Halpenny, E. 2006. Environmental behaviour, place attachment and park visitation: A case study of visitors to Point Pele National Park. Doctoral Thesis, University of Waterloo.

Henkel, S., T. Tomczak, M. Heitmann, and A. Herrmann. 2007. Managing brand consistent employee behaviour: Relevance and managerial control of behavioural branding. Journal of Product \& Brand Management 16 (5): 310-320.

Hennig-Thurau, T., K.P. Gwinner, and D.D. Gremler. 2002. Understanding relationship marketing outcomes: An integration of relational benefits and relationship quality. Journal of Service Research 4 (3): 230-247.

Homburg, C., M. Klarmann, and J. Schmitt. 2010. Brand awareness in business markets: When is it related to firm performance?
International Journal of Research in Marketing 27 (3): 201-212.

Hosany, S., G. Prayag, R. Van Der Veen, S. Huang, and S. Deesilatham. 2017. Mediating effects of place attachment and satisfaction on the relationship between tourists' emotions and intention to recommend. Journal of Travel Research 56 (8): 1079-1093.

Hovland, C.I., I.L. Janis, and H.H. Kelley. 1953. Communication and persuasion in psychological studies of opinion change. New Haven: Yale University Press.

Hovland, C.I., and W. Weiss. 1951. The influence of source credibility on communication effectiveness. Public Opinion Quarterly 15 (4): 635-650.

Hu, L., and P.M. Bentler. 1999. Cutoff criteria for fit indexes in covariance structure analysis: Conventional criteria versus new alternatives. Structural Equation Modeling: A Multidisciplinary Journal 6 (1): 1-55.

Hur, W., H. Kim, and J. Woo. 2014. How CSR leads to corporate brand equity: Mediating mechanisms of corporate brand credibility and reputation. Journal of Business Ethics 125 (1): 75-86.

Jiménez-Barreto, J., N. Rubio, S. Campo, and S. Molinillo. 2020. Linking the online destination brand experience and brand credibility with tourists' behavioral intentions toward a destination. Tourism Management 79: 104101.

Jin, N., S. Lee, and J. Jun. 2015. The role of brand credibility in predicting consumers' behavioral intentions in luxury restaurants. Anatolia 26 (3): 384-396.

Johnson, H.H., J.M. Torcivia, and M.A. Poprick. 1968. Effects of source credibility on the relationship between authoritarianism and attitude change. Journal of Personality and Social Psychology 9 (2): 179-183.

Karanges, E., K.A. Johnston, I. Lings, and A.T. Beatson. 2018. Brand signalling: An antecedent of employee brand understanding. Journal of Brand Management 25 (3): 235-249.

Kavaratzis, M., and M.J. Hatch. 2013. The dynamics of place brands: An identity-based approach to place branding theory. Marketing Theory 13 (1): 69-86.

Kline, R.B. 2015. Principles and practice of structural equation modeling. New York: Guilford Publications.

Kyle, G., A. Graefe, R. Manning, A. Library, and C. Raymond. 2004. Attached recreationists... Who are they? Journal of Recreation and Parks Administration 22 (2): 65-84.

Lam, T., and C.H.C. Hsu. 2006. Predicting behavioral intention of choosing a travel destination. Tourism Management 27 (4): 589-599.

Lutz, R.J., S. MacKenzie, and G.E. Belch. 1983. Attitude toward the ad as a mediator of advertising effectiveness: Determinants and consequences. In Advances in consumer research, ed. R.P. Bagozzi and A.M. Tybout, 532-539. Ann Arbor, MI: Associations for Consumer Research.

Malhotra, N.K., S.S. Kim, and A. Patil. 2006. Common method variance in IS research: A comparison of alternative approaches and a reanalysis of past research. Management Science 52 (12): $1865-1883$.

Mikulincer, M. 1998. Attachment working models and the sense of trust: An exploration of interaction goals and affect regulation. Journal of Personality and Social Psychology 74 (5): 1209-1224.

Mikulincer, M., and P.R. Shaver. 2007. Attachment in adulthood: Structure, dynamics and change. New York: The Guilford Press.

Mittal, V., P. Kumar, and M. Tsiros. 1999. Attribute-level performance, satisfaction, and behavioral intentions over time: A consumptionsystem approach. Journal of Marketing 63 (2): 88-101.

Morgan, R.M., and S.D. Hunt. 1994. The commitment-trust theory of relationship marketing. Journal of Marketing 58 (3): 20-38.

Muthén, L.K., and B.O. Muthén. 1998-2012. Mplus user's guide (5th ed.). Los Angeles: Muthén \& Muthén. 
Nawijn, J., O. Mitas, Y. Lin, and D. Kerstetter. 2012. How do we feel on vacation? A closer look at how emotions change over the course of a trip. Journal of Travel Research 52 (2): 265-274.

Nguyen, T.D. 2009. Signal quality and service quality: A study of local and international MBA programs in Vietnam. Quality Assurance in Education 17 (4): 364-376.

Park, C.W., D.J. Macinnis, J. Priester, A.B. Eisingerich, and D. Iacobucci. 2010. Brand attachment and brand attitude strength: Conceptual and empirical differentiation of two critical brand equity drivers. Journal of Marketing 74 (6): 1-17.

Pike, S. 2005. Tourism destination branding complexity. Journal of Product \& Brand Management 14 (4): 258-259.

Podsakoff, P.M., S.B. MacKenzie, and N.P. Podsakoff. 2012. Sources of method bias in social science research and recommendations on how to control it. Annual Review of Psychology 63: 539-569.

Prayag, G., and C. Ryan. 2011. Antecedents of tourists' loyalty to Mauritius: The role and influence of destination image, place attachment, personal involvement, and satisfaction. Journal of Travel Research 51: 342-356.

Qu, H., L.H. Kim, and H.H. Im. 2011. A model of destination branding: Integrating the concepts of the branding and destination image. Tourism Management 32 (3): 465-476.

Rao, A.R., L. Qu, and R.W. Ruekert. 1999. Signaling unobservable product quality through a brand ally. Journal of Marketing Research 36 (2): 258-268.

Reitsamer, B.F., A. Brunner-Sperdin, and N.E. Stokburger-Sauer. 2016. Destination attractiveness and destination attachment: The mediating role of tourists' attitude. Tourism Management Perspectives 19: 93-101.

Schouten, J.W., and J.H. McAlexander. 1995. Subcultures of consumption: An ethnography of the new bikers. Journal of Consumer Research 22: 43-61.

Shan, Y. 2016. How credible are online product reviews? The effects of self-generated and system-generated cues on source credibility evaluation. Computers in Human Behavior 55: 633-641.

Sitkin, S.B. 1992. Learning through failure: The strategy of small losses. Research in Organizational Behavior 14: 231-266.

Spence, A.M. 1974. Market signaling: Informational transfer in hiring and related screening processes. Boston, MA: Harvard University Press.

Sweeney, J., and J. Swait. 2008. The effects of brand credibility on customer loyalty. Journal of Retailing and Consumer Services 15 (3): 179-193.

Tae, H.B., J. Kim, and J.H. Yu. 2010. The differential roles of brand credibility and brand prestige in consumer brand choice. Psychology and Marketing 27 (7): 662-678.

Thomson, M. 2006. Human brands: Investigating antecedents to consumers' strong attachments to celebrities. Journal of Marketing 70: $104-119$

Thomson, M., D.J. MacInnis, and C.W. Park. 2005. The ties that bind: Measuring the strength of consumers' emotional attachments to brands. Journal of Consumer Psychology 15 (1): 77-91.

Tirole, J. 1988. The theory of industrial organization. Cambridge, MA: MIT Press.

Tung, V., and J.R. Ritchie. 2011. Exploring the essence of memorable tourism experiences. Annals of Tourism Research 38: 1367-1386.

Umeogu, B. 2012. Source credibility: A philosophical analysis. Open Journal of Philosophy 2 (2): 112-115.

Veasna, S., W.Y. Wu, and C.H. Huang. 2013. The impact of destination source credibility on destination satisfaction: The mediating effects of destination attachment and destination image. Tourism Management 36: 511-526.

Veloutsou, C., and L. Moutinho. 2009. Brand relationships through brand reputation and brand tribalism. Journal of Business Research 62 (3): 314-322.

Visentin, M., G. Pizzi, M. Pichierri, and M. Pichierri. 2019. Fake news, real problems for brands: The impact of content truthfulness and source credibility on consumers' behavioral intentions toward the advertised brands. Journal of Interactive Marketing 45: 99-112.

Volgger, M., and H. Pechlaner. 2014. Requirements for destination management organizations in destination governance: Understanding DMO success. Tourism Management 41: 64-75.

Wang, Y.-C., C.-R. Liu, W.-S. Huang, and S.-P. Chen. 2020. Destination fascination and destination loyalty: Subjective well-being and destination attachment as mediators. Journal of Travel Research 59 (3): 496-511.

Williams, D.R., and S.L. Stewart. 1998. Sense of place: An elusive concept that is finding a place in ecosystem management. Journal of Forestry 96 (5): 18-23.

Yuksel, A., F. Yuksel, and Y. Bilim. 2010. Destination attachment: Effects on customer satisfaction and cognitive, affective and conative Loyalty. Tourism Management 31 (2): 274-284.

Zeithaml, V.A. 1988. Consumer perceptions of price, quality and value: A means-end model and synthesis of evidence. Journal of Marketing 52 (3): 2-22.

Zeithaml, V.A., L.L. Berry, and A. Parasuraman. 1996. The behavioral consequences of service quality. Journal of Marketing 60 (4): 31-46.

Zenker, S., E. Braun, and S. Petersen. 2017. Branding the destination versus the place: The effects of brand complexity and identification for residents and visitors. Tourism Management 58: 15-27.

Zhao, X., J.G. Lynch Jr., and Q. Chen. 2010. Reconsidering Baron and Kenny: Myths and truths about mediation analysis. Journal of Consumer Research 37 (2): 197-206.

Publisher's Note Springer Nature remains neutral with regard to jurisdictional claims in published maps and institutional affiliations.

Bernd F. Reitsamer, PhD is an Assistant Professor in Service Management at the University of Innsbruck, Austria. His research focuses on experiential marketing, digitization, and multi-channel management in service settings. He has served as Associate Dean of Studies for the master program Strategic Management and has published his research in journals such as Psychology \& Marketing, Tourism Management Perspectives, or Journal of Vacation Marketing. Dr. Reitsamer is involved into marketing consulting projects on a regular basis.

Prof. (FH) Dr. Alexandra Brunner-Sperdin is a Professor of Marketing and Vice Dean of Studies in Marketing \& Communications (Bachelor) and Digital Marketing (Master) at the Kufstein University of Applied Studies, Austria. Her research has been published in leading academic journals such as Marketing Letters and Journal of Business Research. She co-authored several books on services marketing and customer experience. Her area of expertise is customer and destination experience in offline and online settings, service design, and customer decision-making. 